\title{
Teaching NeuroImages: Unilateral focal segmental hyperhidrosis from spinal tumor progression
}

Christopher S. Hong, MD, Adam J. Kundishora, MD, Kristopher T. Kahle, MD, PhD, and Michael L. Diluna, MD Neurology ${ }^{\circledR}$ 2019;93:e729-e730. doi:10.1212/WNL.0000000000007950

A 10-year-old girl presented with excessive sweating overlying her right scapula (figure) and stable right leg weakness due to an underlying solid cystic pilocytic astrocytoma spanning T3-T12, debulked 5 months earlier, subsequently re-decompressed with syringosubarachnoid shunt placement secondary to intrasyrinx hemorrhage. MRI demonstrated mild tumor and syrinx progression at T5-T8, limited to the right side (figure, B-E). Focal segmental hyperhidrosis is rare, previously reported in Chiari and traumarelated syringomyelia. ${ }^{1,2}$ Here, unilateral hyperhidrosis was caused by ipsilateral tumor and syrinx progression. The pathophysiology may be from local tissue damage causing hyperactivity of preganglionic sympathetic neurons or disinhibition of inhibitory local interneurons. ${ }^{2}$

\section{Author contributions}

C.S. Hong: drafting/revising the manuscript, data acquisition, study concept or design, analysis or interpretation of data, accepts responsibility for conduct of research and final approval,

\section{Correspondence}

Dr. Diluna

michael.diluna@yale.edu

\section{MORE ONLINE}

$\rightarrow$ Teaching slides

links.lww.com/WNL/

A939

Figure Photograph and imaging

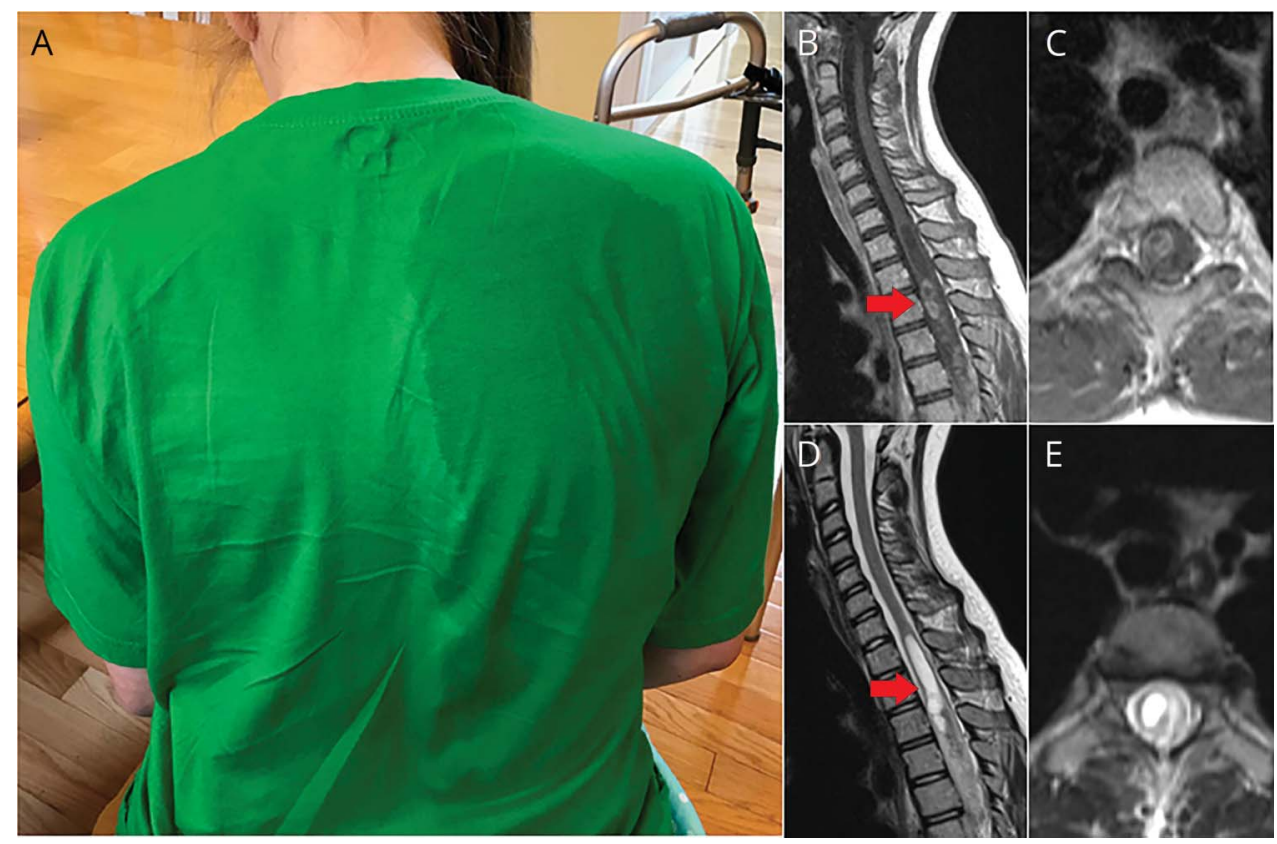

(A) Photograph after physical therapy demonstrates unilateral sweat staining, overlying the right scapula. (B) Sagittal postcontrast T1-weighted MRI shows tumor at T3 (arrow), affecting the (C) right side of the spinal cord. (D) Sagittal T2-weighted MRI illustrates large T2-4 syrinx centered at T3 (arrow) with (E) right-sided predominance.

From the Departments of Neurosurgery (C.S.H., A.J.K., K.T.K., M.L.D.) and Pediatrics (K.T.K., M.L.D.), Yale School of Medicine, New Haven, CT. 
acquisition of data, study supervision. A.J. Kundishora: drafting/revising the manuscript, data acquisition, study concept or design, accepts responsibility for conduct of research and final approval, study supervision. K.T. Kahle: drafting/revising the manuscript, data acquisition, study concept or design, analysis or interpretation of data, accepts responsibility for conduct of research and final approval, obtaining funding. M.L. Diluna: drafting/revising the manuscript, data acquisition, study concept or design, analysis or interpretation of data, accepts responsibility for conduct of research and final approval, study supervision.

\section{Study funding}

No targeted funding reported.

\section{Disclosure}

The authors report no disclosures relevant to the manuscript. Go to Neurology.org/ $\mathrm{N}$ for full disclosures.

\section{References}

1. Glasauer FE, Czyrny JJ. Hyperhidrosis as the presenting symptom in post-traumatic syringomyelia. Paraplegia 1994;32:423-429.

2. Sudo K, Fujiki N, Tsuji S, et al. Focal (segmental) dyshidrosis in syringomyelia J Neurol Neurosurg Psychiatry 1999;67:106-108. 


\section{Neurology}

\section{Teaching NeuroImages: Unilateral focal segmental hyperhidrosis from spinal tumor progression}

Christopher S. Hong, Adam J. Kundishora, Kristopher T. Kahle, et al. Neurology 2019;93;e729-e730

DOI 10.1212/WNL.0000000000007950

This information is current as of August 12, 2019

\section{Updated Information \&} Services

\section{References}

Subspecialty Collections

Permissions \& Licensing

Reprints including high resolution figures, can be found at: http://n.neurology.org/content/93/7/e729.full

This article cites 2 articles, 1 of which you can access for free at: http://n.neurology.org/content/93/7/e729.full\#ref-list-1

This article, along with others on similar topics, appears in the following collection(s):

Spinal cord tumor

http://n.neurology.org/cgi/collection/spinal_cord_tumor Surgical therapy-tumor

http://n.neurology.org/cgi/collection/surgical_therapytumor

Information about reproducing this article in parts (figures,tables) or in its entirety can be found online at:

http://www.neurology.org/about/about_the_journal\#permissions

Information about ordering reprints can be found online:

http://n.neurology.org/subscribers/advertise

Neurology ${ }^{\circledR}$ is the official journal of the American Academy of Neurology. Published continuously since 1951, it is now a weekly with 48 issues per year. Copyright (O 2019 American Academy of Neurology. All rights reserved. Print ISSN: 0028-3878. Online ISSN: 1526-632X.

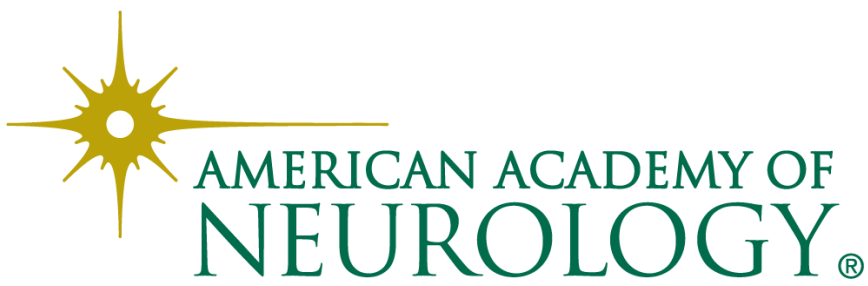

